УДК 591.69-7(-87)+597.554.4(-87)

\title{
Two New Metacercariae \\ of Genus Austrodiplostomum (Trematoda: Diplostomidae) \\ from Oreochromis niloticus (Cichlidae) \\ and Varicorhinus beso (Cyprinidae) \\ in Tana Lake, Ethiopia
}

\author{
Alexandr E. Zhokhov* and Maria N. Pugacheva \\ Papanin Institute for Biology of Inland Waters RAS \\ Borok, Yaroslavl oblast, 152742, Russia
}

Received 27.07.2016, received in revised form 28.07.2016, accepted 10.09.2016

\begin{abstract}
Metacercariae of two new trematode species of the genus Austrodiplostomum are described from fishes of Tana Lake in Ethiopia: Austrodiplostomum sp. 1 from cranial cavity of Oreochromis niloticus and Austrodiplostomum sp. 2 from vitreous humor of Varicorhinus beso. New species metacercariae differs from A. mordax metacercariae in the shape of body, the size of body and organs, the shape of anterior extremity, and site of infection. This is the first record of Austrodiplostomum metacercariae from fish in Africa.
\end{abstract}

Keywords: Austrodiplostomum, Trematoda, new species, metacercaria, fish, Africa.

Citation: Zhokhov A.E., Pugacheva M.N. Two new metacercariae of genus Austrodiplostomum (Trematoda: Diplostomidae) from Oreochromis niloticus (Cichlidae) and Varicorhinus beso (Cyprinidae) in Tana Lake, Ethiopia. J. Sib. Fed. Univ. Biol., 2018, 11(1), 88-96. DOI: 10.17516/1997-1389-0047.

(c) Siberian Federal University. All rights reserved

* Corresponding author E-mail address: zhokhov@ibiw.yaroslavl.ru 


\title{
Две новых метацеркарии
}

\author{
рода Austrodiplostomum (Trematoda: Diplostomidae) \\ из Oreochromis niloticus (Cichlidae) \\ и Varicorhinus beso (Cyprinidae) в оз. Тана, Эфиопия
}

\author{
А.Е. Жохов, М.Н. Пугачева \\ Институт биологии внутренних вод \\ им. И.Д. Папанина РАН \\ Россия, 152742, Ярославская обл., п. Борок
}

\begin{abstract}
Из рыб оз. Тана в Эфиопии описаны метацеркарии двух новых видов трематод рода Austrodiplostomum: метацеркария Austrodiplostomum sp. 1 из черепной полости Oreochromis niloticus и Austrodiplostomuт sp. 2 из стекловидного тела глаза Varicorhinus beso. Новые виды метачеркарий отличаются от метачеркарии А. тогdах формой тела, размерами тела и органов, формой переднего кониа тела и локализацией в хозяине. Это первая регистрация метаиеркарий рода Austrodiplostoтит у рыб Африки.
\end{abstract}

Ключевые слова: Austrodiplostomит, Trematoda, новый вид, метацеркария, рыбы, Африка.

\section{Introduction}

Genus Austrodiplostomum Szidat et Nani 1951 belong to the subfamily Diplostominae Poirier, 1886 of the family Diplostomidae Poirier, 1886 (Niewiadomska, 2002). Before this study, the genus Austrodiplostomum was represented by three species: A. compactum Lutz, 1928, A. mordax Szidat et Nani, 1951 (Szidat \& Nani, 1951), and A. ostrowskiae Dronen, 2009 (Dronen, 2009). All of them as adult are endohelminthic parasites of cormorants (Lutz, 1928; Szidat \& Nani, 1951; Ostrowski de Núñez, 1970; Dubois \& Macko, 1972; Nasir \& Díaz, 1972; Dubois, 1977; Rietschel \& Werding, 1978; Fedynich et al., 1997; Dronen, 2009) and freshwater fishes (Machado et al., 2005; Salgado-Maldonado, 2006; Novaes et al., 2006; Violante-González et al., 2009) in the western hemisphere. A three-host life cycle of Austrodiplostomum includes gastropods of the genus Biomphalaria Preston, 1910 as first intermediate host (Rosser et al., 2016). As metacercariae the genus Austrodiplostomum was represented by $A$. compactum (Lutz, 1928) Dubois, 1970, A. mordax (Szidat et Nani, 1951) n. comb., and A. ostrowskiae Dronen, 2009. These metacercariae are parasites of different South American, Central American and North American freshwater fishes.

During recent investigations into the parasites of some fishes in Tana Lake (Ethiopia), specimens of two Austrodiplostomum species were found in the brain and vitreous humor of Oreochromis niloticus and Varicorhinus beso, respectively. A closer examination of this material, made it possible to describe a two new species as metacercariae. The results of this study are presented herein.

\section{Materials and methods}

In September-November 2006-2008, samples of Nile tilapia Oreochromis niloticus (Linnaeus, 1758) (82 specimens, mean length 
\pm SE: $12.9 \pm 0.7 \mathrm{~mm}$, range $9-260 \mathrm{~mm}$ ) and Khramulya Varicorhinus beso Rüppell, 1835 (25 specimens, $15.1 \pm 0.9 \mathrm{~mm}$, range $70-215 \mathrm{~mm}$ ) were taken from Bahar-Dar Gulf of Tana Lake, Ethiopia ( $\left(11^{\circ} 33^{\prime} \mathrm{N}, 37^{\circ} 22^{\prime} \mathrm{E}\right)$. Fish captures were undertaken using gill nets. The eyes and brain of all individuals were examined. Live worms were rinsed in saline, briefly examined prior to fixation, killed with hot water, and fixed in $70 \%$ ethanol. A total 56 specimens of metacercariae from $O$. niloticus and 35 specimens from $V$. beso were collected. Whole-mounts were stained with alum carmine, cleared in dimethyl phthalate and mounted in Canada balsam. Measurements were taken from whole-mounts and are expressed in micrometers $(\mu \mathrm{m})$.

\section{Results}

Family DIPLOSTOMIDAE Poirier, 1886

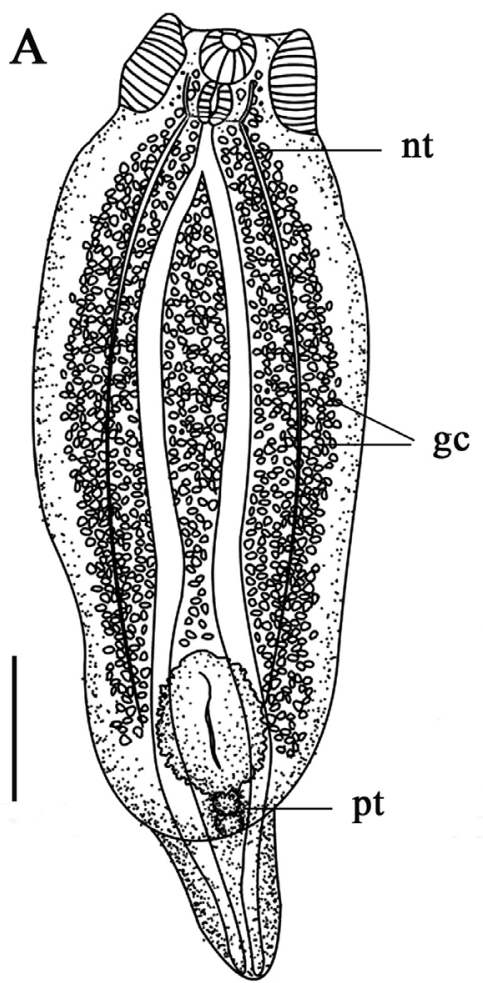

Subfamily DIPLOSTOMINAE Poirier, 1886

Genus AUSTRODIPLOSTOMUM Szidat et Nani, 1951

Austrodiplostomum sp. 1. Fig. 1A, 2 (1-4)

Host: Oreochromis niloticus (Perciformes: Cichlidae).

Site of infection: cranial cavity.

Material studied: 56 specimens.

Locality: Tana Lake near Bahar-Dar, Ethiopia $\left(11^{\circ} 33^{\prime} \mathrm{N}, 37^{\circ} 22^{\prime} \mathrm{E}\right)$.

Specimens deposited: No. 5/407(1-4) (four slides), the Helminthological Collection of the Institute for Biology of Inland Waters RAS and No. 1113 (one slide), the Helminthological Museum of the Parasitological Center of the Institute of Problem of Ecology and Evolution, RAS.

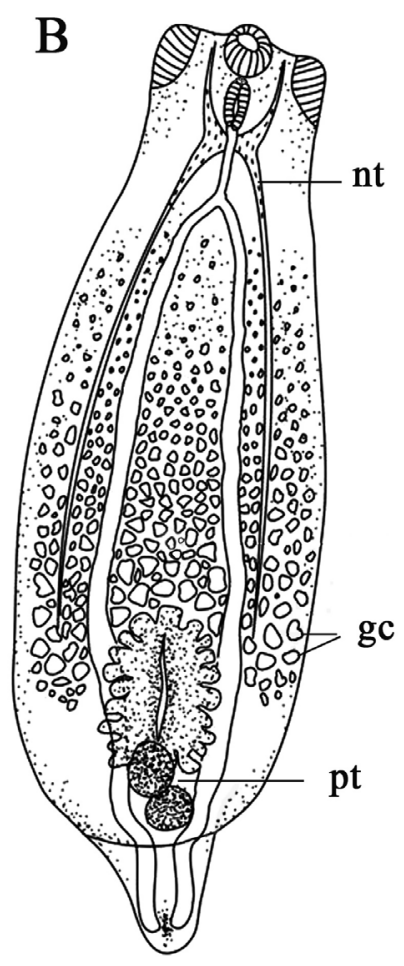

Fig. 1. Austrodiplostomum sp. 1 metacercaria (A), Austrodiplostomum sp. 2 metacercaria (B). Legend: $p t$ - primordium of testes; $n t$ - nerve trunk; $g c$ - glandular cells. Scale bars: A - $200 \mu \mathrm{m}$; B - $100 \mu \mathrm{m}$ 
Prevalence and intensity: 21 of $82(25.6 \%)$, $1-17$.

Description (based on 15 whole-mounted specimens): measurements of the entire series are given in Table. Metacercariae are large. Body elongate, bisegmented, with clear margin between segments, ventral cavity not well developed, maximum width of body at level of middle of anterior segment length. Anterior segment in form of elongated oval, posterior segment conical and elongated. Oral sucker scyphiform, terminal, width slightly greater than length. At the sides of oral sucker, there are well developed elongated pseudosuckers, situated always above level of oral sucker (Fig. 2). Pseudosuckers longer and narrower than oral sucker. Ventral sucker lacking. Prepharynx absent, pharynx oval, well developed, esophagus short. Intestinal bifurcation in anterior fourth of anterior segment. Intestinal caeca wide or narrow, reached to posterior extremity. Brandes' organ oval, with elongate, wide slitlike opening, lateral and posterior margins pinnately lobed. Primordium of two testes round or oval, one behind another or slightly diagonal, situated between Brandes' organ and posterior margin of anterior segment, in some specimens primordium of posterior testes lie in posterior segment of body. Anterior three fourth of body filled with numerous glandular cells, extending from cecal bifurcation to Brandes' organ. Laterally glandular cells subside to middle or anterior part of Brandes' organ. Nerve trunks and commissure are visible.

Remarks. The present form is identical in structure to A. mordax, A. compactum, and A. ostrowskiae metacercaria from different fishes in South America. The characters differentiating this species from their American congeners include the size of body and organs, absence of the prepharynx and shape of anterior extremity. The new species differs from $A$. compactum and
A. ostrowskiae by the smaller body, oral sucker, pseudosuckers, pharynx, esophagus and Brandes' organ, but longer posterior segment of body. The feature separating Austrodiplostomum sp. 1 and their American congeners is the different structure of anterior extremity. The pseudosuckers of Austrodiplostomum sp. 1 were situated above level of oral sucker, whereas those of American Austrodiplostomum were situated below level of oral sucker.

Austrodiplostomum sp. 2. Fig. 1B, 2 (5-8)

Host: Varicorhinus beso (Cypriniformes: Cyprinidae).

Site of infection: vitreous humor.

Material studied: 35 specimens.

Locality: Tana Lake near Bahar-Dar, Ethiopia $\left(11^{\circ} 33^{\prime} \mathrm{N}, 37^{\circ} 22^{\prime} \mathrm{E}\right)$.

Specimens deposited: No. 6/419 (1-5) (five slides), the Helminthological Collection of the Institute for Biology of Inland Waters RAS.

Prevalence and intensity: 2 of 17 (11.8\%), 12-18.

Description (based on 15 whole-mounted specimens): measurements of the entire series are given in Table. Body oblong, bipartite, expanded posterior to middle of anterior segment, maximum width of body near anterior margin of Brandes' organ. Ventral cavity not well developed. Anterior segment oval, posterior segment in form of elongate bulge. Oral sucker scyphoid, terminal, length slightly greater than width. Pseudosuckers oval, situated lateral and lower to oral sucker (Fig. 2). Pseudosuckers longer and wider than oral sucker. Ventral sucker lacking. Prepharynx absent. Pharynx oval, muscular, esophagus short. Intestinal bifurcation at approximately border of first and second fourth of anterior segment. Intestinal caeca wide with patent lumen, extends almost to posterior end. Brandes' organ oval, with median longitudinal slit, its margins deeply lobed. Testicular primordial round or oval, slightly 


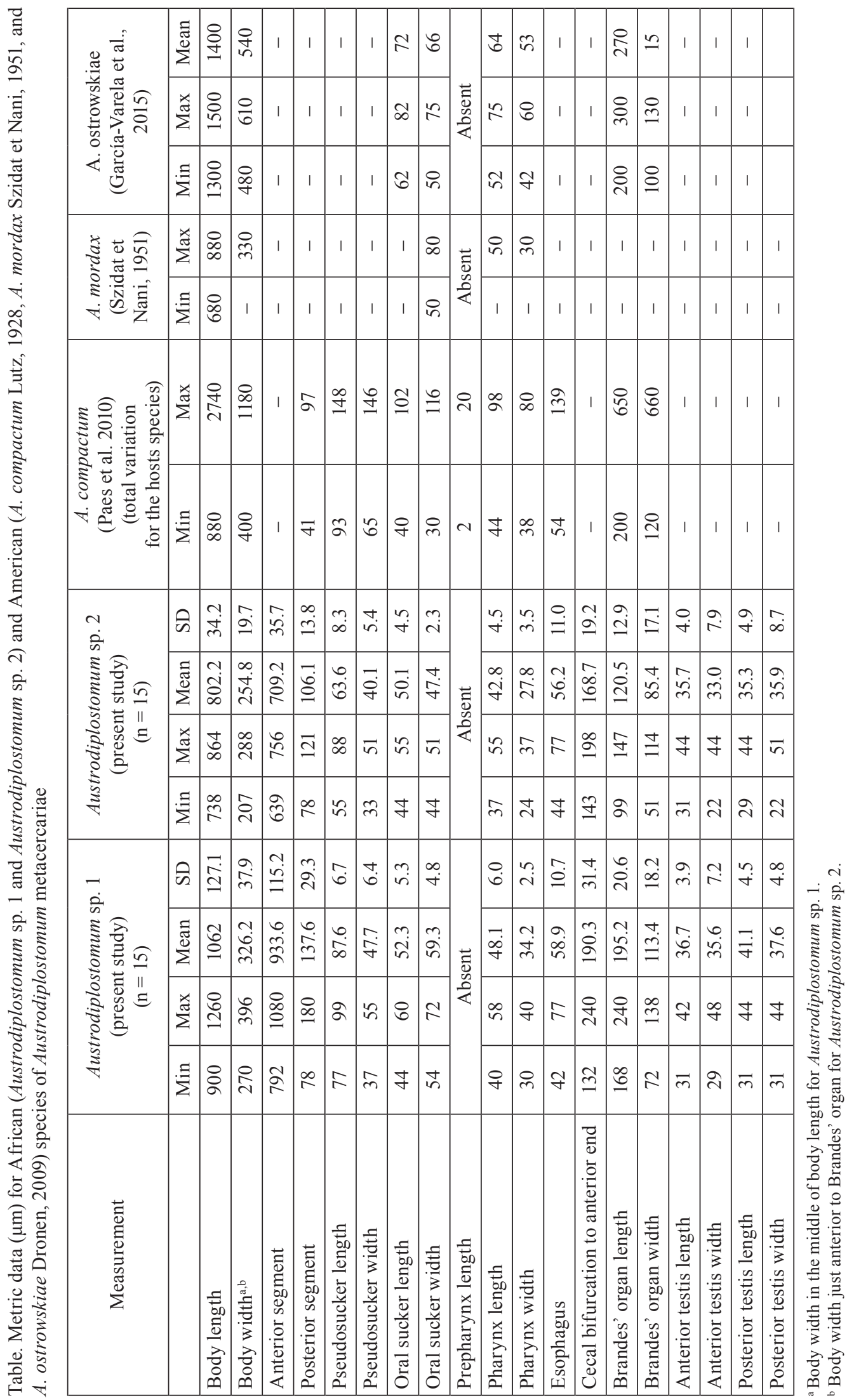




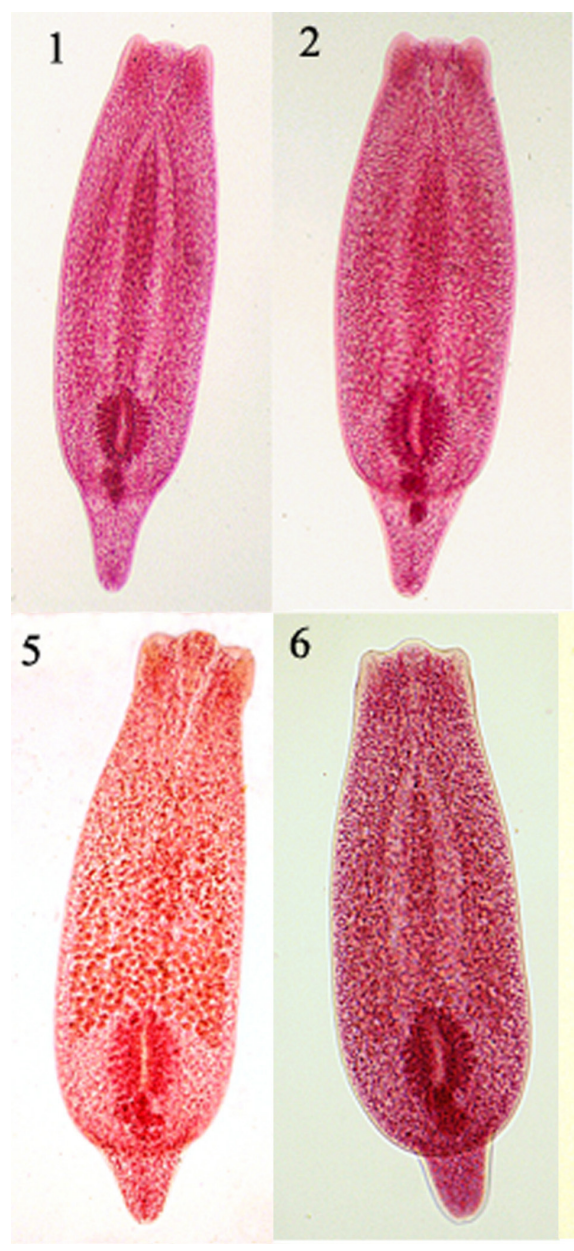

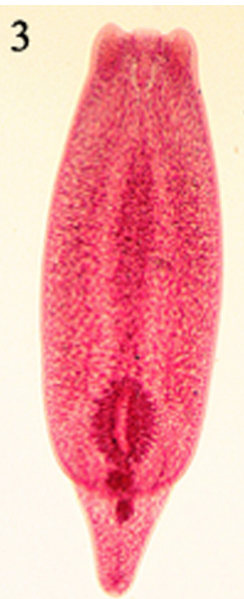

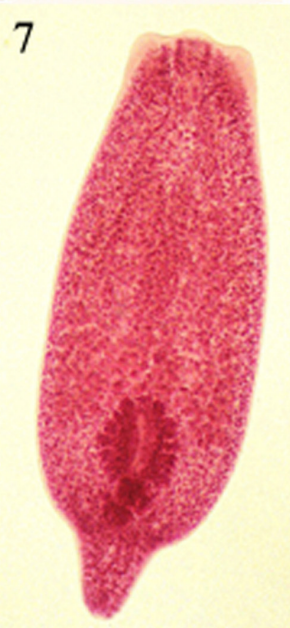

4
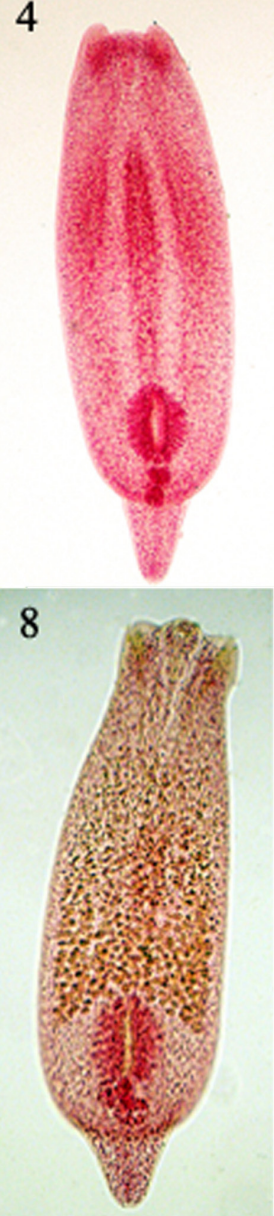

Fig. 2. Austrodiplostomum sp. 1 from cranial cavity of Oreochromis niloticus, 1-4, view of entire metacercaria; Austrodiplostomum sp. 2 from vitreous humor of Varicorhinus beso, 5-8, view of entire metacercaria

diagonal, situated between Brandes' organ and posterior margin of anterior segment. Numerous glandular cells fill most part of body anterior to Brandes' organ. Laterally glandular cells subside to level of the beginning of Brandes' organ. Size of glandular cells noticeably increases from cecal bifurcation to Brandes' organ. Nerve trunks and commissure are visible.

Remarks. The metacercariae of Austrodiplostomum sp. 2 closely resemble those of Austrodiplostomum sp. 1 described above. Austrodiplostomum sp. 2 differs from Austrodiplostomum sp. 1 in its body shape, relatively shorter posterior segment, smaller body size and organs size, larger glandular cells and the structure of anterior extremity. The pseudosuckers of Austrodiplostomum sp. 2 situate below level of oral sucker, whereas those of Austrodiplostomum sp. 1 situate above level of oral sucker. In addition, the pseudosuckers of Austrodiplostomum sp. 2 are relatively rounded and shorter than those of Austrodiplostomum sp. 1. The maximum of body width is positioned near anterior margin of Brandes' organ in Austrodiplostomum sp. 2 compared with at level of middle of anterior segment length in Austrodiplostomum sp. 1. 
The larva of Austrodiplostomum sp. 2 morphologically corresponds to metacercaria of Austrodiplostomum from American fishes. Both of them have the relatively rounded pseudosuckers situated below level of oral sucker and relatively shorter posterior segment. This species differs from American congeners by having a smaller body size. The body size, pseudosuckers and pharynx size, oral sucker and Brandes' organ size in Austrodiplostomum sp. 2 are approximately two times smaller than those in A. compactum and A. ostrowskiae. Furthermore, in A. mordax and $A$. compactum the glandular cells just extend to apex of Brandes' organ, in Austrodiplostomum sp. 2 they extend markedly below of apex of Brandes' organ.

\section{Discussion}

This is the first record of the genus Austrodiplostomum from Africa. The description of two new species increases the number of species in the genus to a total of five; the two previously described species being A. mordax, A. compactum, and A. ostrowskiae. The finding of new species of Austrodiplostomum in Africa means that the genus has now been found from both hemispheres of the world.

Metacercariae of Austrodiplostomum sp. 1 and Austrodiplostomum sp. 2 are clearly distinguishable. The characters differentiating these species one from another include the shape of body, the size of body and organs, the shape of anterior extremity, and these differences are fundamental. At the same time, the metacercariae of American species (A. mordax and $A$. compactum) have not clear morphological differences (Dubois, 1970; Ostrowski de Núñez, 1977).

American metacercaria of Austrodiplostomum have wide specificity and occur in a broad spectrum of fish hosts (65 fish species) (Kohn et al., 1995; Viozzi \&
Flores, 2002; Machado et al., 2005; SalgadoMaldonado， 2006; Violante-González \& Aguirre-Macedo, 2007; Violante-González et al., 2007; Paes et al., 2010; Zica et al., 2010; García-Varela et al., 2015). In contrast to American species Austrodiplostomum African species Austrodiplostomum exhibit narrow host specificity. Of the eight fish species (Clarias gariepinus Burchell, 1822, Barbus tanapelagius Graaf et al., 2000, B. humilis Boulenger, 1902, B. pleurogramma Boulenger, 1902, Garra dembecha Getahun et Stiassny, 2007, Labeobarbus intermedius Rüppell, 1835, V. beso, O. niloticus) studied in Tana Lake, only $V$. beso and $O$. niloticus harboured metacercariae Austrodiplostomum sp. 1 and Austrodiplostomum sp. 2, respectively. The absence of infection in other fish species may be related to specificity of these metacercariae.

Herewith site of infection with African species of Austrodiplostomum metacercariae differs from the site infection of American species. Species of Austrodiplostomum sp. 1 and Austrodiplostomum sp. 2 are confined to the vitreous humor and cranial cavity, respectively, whereas that of metacercariae of $A$. mordax, A. compactum, and A. ostrowskiae are the vitreous humor (mainly), brain, mesentery, swim bladder, fins, muscles (Salgado-Maldonado, 2006; GarcíaVarela et al., 2015; Zica et al., 2010).

The potential definitive hosts of Austrodiplostomum sp. 1 and Austrodiplostomum sp. 2 may be cormorants Phalacrocorax carbo (Linnaeus, 1758) and P. africanus (Gmelin, 1789) and darter Anhinga rufa (Daudin, 1802) which are residents in Tana Lake (Nagelkerke, 1997).

\section{Acknowledgements}

The field studies on which this work is based were conducted within the framework of a Joint Ethio-Russian Biological Expedition (JERBE-II) financially supported by the Russian Academy 
of Sciences. We thank Dr. Andrei Darkov, Dr. Eshete Dejen and Mr. Tadesse Gebre-Selassie for their assistance. The authors thank Daria Morozova for preparation of Fig. 1.

\section{References}

Dronen N.O. (2009) Austrodiplostomum ostrowskiae n. sp. (Digenea: Diplostomidae: Diplostominae) from the Double-crested Cormorant, Phalacrocorax auritus (Phalacrocoracidae) from the Galveston, Texas Area of the Gulf of Mexico, U.S.A. Comp. Parasitol., 76: 34-39

Dubois G. (1970) Les Strigeata (Trematoda) de la collection A. Lutz. Memórias do Instituto Oswaldo Cruz, Rio de Janeiro, 68: 169-196

Dubois G. (1977) Du Statut de Quelques Strigeata La Rue, 1926 (Trematoda). V. Bulletin de la Société neuchateloise des Sciences naturalles, 100: 35-44

Dubois G., Macko J.K. (1972) Contribution á l'étude des Strigeata La Rue, 1926 (Trematoda: Strigeida) de Cuba. Annales de Parasitologie Humaine et Comparée, 47: 51-75

García-Varela M., Sereno-Uribe A.L., Pinacho-Pinacho C.D., Domínguez-Domínguez O., Pérez-Ponce de León G. (2015) Molecular and morphological characterization of Austrodiplostomum ostrowskiae Dronen, 2009 (Digenea: Diplostomatidae), a parasite of cormorants in the Americas. J. Helminthol., 90(2): 174-185

Fedynich A.M., Pence D.B., Bergan J.F. (1997) Helminth community structure and pattern in sympatric populations of double-crested and neotropical cormorants. J. Helminthol. Soc. Wash., 64: $176-182$

Kohn A., Fernandes B.M.M., Baptista-Farias M.F.D. (1995) Metacercariae of Diplostomum (Austrodiplostomum) compactum (Trematoda, Diplostomidae) in the eyes of Plagioscion squamosissimus (Teleostei, Sciaenidae) from the reservoir of the hydroelectric power station of Itaipu, Brazil. Memory Institute of Oswaldo Cruz, Rio de Janeiro, 90: 341-344

Lutz A. (1928) Estudios de zoología y parasitología Venezolanas. Universidad Central de Venezuela, Caracas, $133 \mathrm{p}$.

Machado P.M., Takemoto R.M., Pavanelli G.C. (2005) Diplostomum (Austrodiplostomum) compactum (Lutz, 1928) (Platyhelminthes, Digenea) metacercariae in fish from the floodplain of the Upper Parana' River, Brazil. Parasitol. Res., 97: 436-444

Nagelkerke L.A.J. (1997) The barbs of Lake Tana, Ethiopia - morphological diversity and its implication for taxonomy, trophic resource partitioning, and fisheries. Diss. Doct. Phil., Wageningen Agricultural University. Wageningen, the Netherlands, 296 p.

Nasir P., Díaz M.T. (1972) Avian flukes of Venezuela. Rivista di Parassitologia, 33: 245276

Niewiadomska K. (2002) Family Diplostomidae Poirier, 1886. Keys to the Trematoda, Vol. 1. Gibson D.I., Jones A., Bray R.A. (eds.) Wallingford, CABI Publishing and the Natural History Museum, p. $167-196$

Novaes J.L.C., Ramos I.P., Carvalho E.D., Silva R.J. (2006) Metacercariae of Diplostomum compactum Lutz, 1928 (Trematoda, Diplostomidae) in the eyes of acara Geophagus brasiliensis Quoy \& Gaimard, 1824 (Teleostei, Cichlidae) from Barra Bonita Reservoir - São Paulo, Brazil. Arquivo Brasileiro de Medicina Veterinária e Zootecnia, 58: 1229-1231 
Ostrowski de Núñez M. (1970) Estudios sobre la fauna parasitaria del bigua, "Phalacrocorax b. brasilianus". II. Trematodes pertenecientes al la familia "Diplostomatidae" Poirier, 1886. Revista del Museo Argentino de Ciencias Naturales Bernardino Rivadavia. Zoología, 10: 199-214

Ostrowski de Núñez M. (1977) El ciclo biológico de Diplostomum (Austrodiplostomum) compactum (Lutz, 1928) Dubois, 1970 (=Austrodiplostomum mordax Szidat y Nani, 1951) (Trematoda, Diplostomatidae). Revista del Museo Argentino de Ciencias Naturales Bernardino Rivadavia, Parasitología, 2: 7-74

Paes J.V.K., Carvalho E.D., Silva R.J. (2010) Infection by Austrodiplostomum compactum metacercariae in fish from the Nova Avanhandava reservoir, Tietê river, São Paulo State, Brazil. Acta Scientiarum. Biological Sciences. Maringá, 32: 273-278

Rietschel G., Werding B. (1978) Trematodes of birds from Northern Columbia. Parasitenkunde, 82: $57-87$

Rosser T.G., Alberson N.R., Khoo L.H., Woodyard E.T., Pote L.M., Griffin M.J. (2016) Characterization of the life cycle of a fish eye fluke, Austrodiplostomum ostrowskiae (Digenea: Diplostomidae), with notes on two other Diplostomids infecting Biomphalaria havanensis (Mollusca: Planorbidae) from catfish aquaculture ponds in Mississippi, USA. J. Parasitol., 102 (2): 260-274

Salgado-Maldonado G. (2006) Checklist of helminthes parasites of freshwater fishes from Mexico. Zootaxa, 1324: 1-357

Szidat L., Nani A. (1951) Diplostomiasis cerebralis del Pejerrey. Una grave Epizootia que afecta a la Economía Nacional producida por larvas de Trematodes que destruyen el cerebro de los pejerreyes. Revista del Instituto Nacional de Investigaciones de las Ciencias Naturales (Argentina), 1: 323-394

Violante-González J., Aguirre-Macedo M.L. (2007) Metazoan parasites of fishes from Coyuca Lagoon, Guerrero, Mexico. Zootaxa, 1531: 39-48

Violante-González J., Aguirre-Macedo M.L., Mendoza-Franco E.F. (2007) A checklist of metazoan parasites of fish from Tres Palos lagoon, Guerrero, Mexico. Parasitol. Res., 102: 151-161

Violante-González J., García-Varela M., Rojas-Herrera A., Gil Guerrero S. (2009) Diplostomiasis in cultured and wild tilapia Oreochromis niloticus in Guerrero State, Mexico. Parasitol. Res., 105: 803-807

Viozzi G.P., Flores V.R. (2002) Population dynamics of Tylodelphys destructor and Diplostomum mordax (Digenea: Diplostomidae) co-occurring in the brain of Patagonian silversides from Lake Pellegrini, Patagonia, Argentina. J. Wildlife Diseas., 38: 784-788

Zica E.O.P., Brandão H., Zawadzki C.H., Nobile A.B., Carvalho E.D., da Silva R.J. (2010) The occurrence of Austrodiplostomum compactum (Lutz, 1928) (Digenea: Diplostomidae) metacercariae in the eyes of loricariid fish (Siluriformes: Osteichthyes: Loricariidae) from Brazil. J. Helminthol., 85 (1): 73-90 